Игорь Иванович КАЛИГАНОВ 


\section{ПРОСВЕТИТЕЛЬ \\ И НЕБЕСНЫЙ ПОКРОВИТЕЛЬ СЕРБИИ \\ СВ. АРХИЕПИСКОП САВВА ${ }^{1}$}

\section{Аннотация:}

В статье рассказывается о св. Савве Сербском (ок. 1169-1235) - крупнейшей фигуре в истории религиозной и культурной жизни православных славян на Балканах в конце XII - первой трети XIII в. Он являлся создателем и предстоятелем автокефальной Сербской церкви, первым распространителем среди сербов сводов церковных и светских законов, первым известным сербским переводчиком и писателем. После смерти Савва был провозглашен святым, сделался одним из главных героев сербской литературы и фольклора, стал почитаться как небесный защитник Сербии и пособник сербского образования.

\section{Ключевые слова:}

Сербия, св. Савва, появление самостоятельной Сербской церкви, начало сербской переводной и оригинальной литературы.

Abstract: I.I. Kaliganov "The ENLIGHTENER AND HEAVENLY DEFENDER OF SERBIA: Holy ARCHBISHOP SAVA".

The article talks about St. Sava of Serbia (c. 1170-1235), the greatest figure in the history of religious and cultural life of the orthodox Slavs in the Balkans in the late 12th to the first third of the 13 th centuries. He was the creator and primate of the autocephalous Serbian Church, the distributor among the Serbs of first codes of church and secular laws and the first known Serbian translator and writer. After his death, Sava was proclaimed a saint, became one of the main heroes of Serbian literature and folklore, and became honored as a heavenly defender of Serbia and protector of Serbian education.

\section{Keywords:}

Serbia, St. Sava, the emergence of an independent Serbian church, the beginning of Serbian translation and original literature.

В. Савва (ок. 1169-1235) - крупнейшая фигура в истории религиозной и культурной жизни православных славян на Балканах конца XII - первой трети XIII столетия, основатель автокефальной Сербской церкви, ее первый архиепископ, первый распространитель среди сербов церковных и светских законов, первый из известных сербских переводчиков и писателей. Был канонизирован как святой сразу же после смерти, один из главных героев сербской средневековой литературы и фольклора, почитается как покровитель образования и защитник Сербии.

1 Работа выполнена при финансовой поддержке РФФИ (грант № 18-512-76004). 


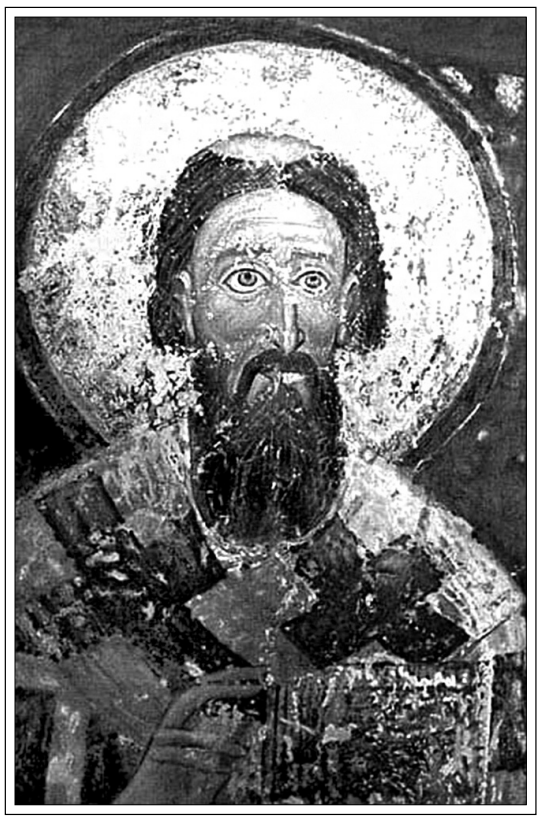

Святой Савва.

Стенопись монастыря Милешево. XIV B.

Растко (таково было светское имя будущего св. Саввы) родился в семье объединителя сербских земель великого жупана (князя) Стефана Немани (1113-1199). Также как его братьям Стефану и Вукану, ему была уготована обычная для сыновей правителя жизнь: женитьба и получение от отца собственной вотчины. Но любящий книгу, набожный Растко по исполнении 16 лет тайно от всех бежал на Афон, где принял монашеский постриг под именем Саввы. Там он надолго обосновался в монастыре Ватопед, подвизался в нескольких афонских обителях и обустроил на Афоне келью для двух-трех сербских монахов с церковью Саввы Освященного. Для них он перевёл с греческого языка и снабдил своими добавлениям так называемый «Карейский типик» - свод строгих монашеских правил, которые легли затем в основу положений о монастырской жизни в скитах Сербии. На щедрые пожертвования своего отца Савва построил на Афоне три храма и жилые корпуса для монахов и паломников.

В 1197 г. его родитель добровольно передал престол своему сыну Стефану, принял монашеский постриг под именем Симеон и удалился в выстроенную им «задужбину» ${ }^{2}-$ обитель Успения Богородицы в Студенице. Чуть позднее он по приглашению Саввы приехал на Афон, после чего на афонские монастыри пролился настоящий дождь пожертвований. За Это Савву в Ватопеде называли «вторым ктитором» - первым являлся византийский император. В 1197 г. отец и сын Неманичи упросили византийского императора Алексия III Ангела даровать им запустевший после нападения пиратов Хиландарский монастырь, чтобы отстроить его для сербского монашества. Позднее, около 1200 г. Савва перевел для этой обители греческий устав константинопольской обители Богородицы Евергетиссы, снабдив свой перевод необходимыми изменениями и дополнениями. Так появился на свет его знаменитый «Хиландарский типик». С той поры Хиландар превратился в один из главных центров духовной жизни средневековой Сербии. 13 февраля 1199 г. отец Саввы умер, и почти сразу же был провозглашен святым, став первым сербом, возведенным в чин святости. Для его канонизации Савва написал житие и службу св. Симеона - пер-

2 Монастырь, который сербские правители обычно строили как собственную усыпальницу в поминовение своей души. 
вые памятники агиографии и гимнографии, заложившие основы сербской оригинальной литературы.

В 1204 г. Савва был поставлен в архимандриты, но на Афоне после этого долго не оставался. В том же году крестоносцы завладели Константинополем (в котором оставались до 1261 г.), и над Афоном нависла реальная угроза захвата его «латинянами». Кроме того, в Сербии вели междоусобную борьбу его братья Стефан и Вукан. Поэтому в 1207 г. Савва покинул Афон и вместе с мироточивыми мощами своего отца св. Симеона переместился в Студеницкий монастырь, сделавшись его игуменом. Через год святитель создал «Студеницкий типик», положив в его основу выполненный им ранее перевод типика для Хиландарской обители. Благодаря своему моральному авторитету Савве удалось примирить братьев, спокойствие в стране было восстановлено, но подвижника очень тревожило усиление в Сербии латинского влияния. На значительной части владений Византии была образована Латинская империя, его брат Стефан, верховный правитель Сербии, принял королевскую корону от Папы и признал себя папским вассалом.

Борясь с усилением латинского влияния, Савва позднее повторно венчал своего брата Стефана как короля, теперь уже по византийскому православному обряду, и тот получил прозвище Первовенчанный. Подвижник начал последовательно добиваться создания независимой Сербской церкви, и его дипломатические усилия вскоре увенчались успехом. В 1218 г. на соборе в Никее национальная церковь сербов была провозглашена автокефальным архиепископством, и на следующий год Савва был избран его главой. Из архиепископской резиденции, монастыря Св. Спаса в Жиче, Савва отправлял своих учеников во все сербские пределы, создавая в них епископские кафедры. Отвечая потребностям сербского государства и церкви, Савва утвердил в Сербии основы церковных и светских законов посредством перевода и приспособления под местные нужды византийского «Номоканона» (или по-славянски «Кормчей»). При составлении этого свода около 1220 г. Савва привлек к работе сербских и русских афонских переводчиков и использовал уже имевшиеся славянские переводы Номоканона (кирилло-мефодиевский IX в. и русский XI в.), различные его византийские редакции и многочисленные более поздние толкования его текста.

В 1229-1230 и 1234-1235 гг. Савва совершил паломничества в Святую землю, причем перед второй поездкой он добровольно передал свой престол своему ученику Арсению. Из Иерусалима подвижник отправлял письма Студеницкому игумену Спиридону и тем самым заложил основы сербской эпистолографии, опиравшейся на византийские традиции. Возвращаясь из второй поездки на родину, Савва умер в болгарской столице Велико Тырново, и был торжественно там погребен. Через год племянник Саввы, король Владислав перевез мощи своего дяди в сербский монастырь св. Вознесения Христова в Милешево. Они стали там объектом поклонения сербов, стекавшихся к ним со всех уголков родных земель на протяжении 
нескольких столетий. Особенно усилилось почитание Саввы как защитника Сербии после завоевания страны турками в середине XV в.

Судьба творений Саввы Сербского во многом определялась их предназначением. «Карейский типик» создавался для конкретного места - монашеской кельи или монастырька, и поэтому сохранился в единственном древнем списке - прижизненном подвижнику, но не в его автографе. Он хранится в библиотеке Хиландарского монастыря. Что же касается общежительного устава самой этой обители, то он был распространен больше и сохранился в нескольких списках, в том числе датируемом не позднее 1206 г. и находящемся в архиве Хиландара. А «Студеницкий типик» Саввы Сербского был адресован монастырской братии и уцелел всего в двух списках 1619 и 1760 гг., хранящихся в Пражском Народном музее и Национальной и университетской библиотеке Загреба. Более широкую известность в славянском мире получил «Номоканон» подвижника, дошедший до нас немалом числе сербских списков XIII-XVI вв., древнейшим из которых является Иловицкий (1262 г.). В 20-х годах XIII столетия перевод «Номоканона» Саввы Сербского попал в Болгарию, а оттуда спустя сорок лет на Русь, где он получил название «Кормчая». На русской почве в XIIIXVII столетиях этот церковно-юридический сборник часто переписывали местные книжники, создав на его основе несколько новых редакций. В середине XVII столетия «Кормчую» Саввы Сербского издали в Московском Печатном дворе со многими дополнениями, после чего издание распространилось на Балканах и оказывало влияние на развитие сербского церковного права по XVIII в. включительно.

Св. Савва является и родоначальником сербской агиографии и гимнографии. Ему принадлежит два жития его отца св. Симеона и служба подвижнику. Первое краткое житие он включил в состав «Хиландарского типика», рассказав о последних днях жизни и кончине своего родителя св. Симеона. Более интересным в литературном и историческом плане является второе из его житий. Оно более пространно и представляет собой введение к «Студеницкому типику» для знакомства монастырской братии с обстоятельствами возникновения монастыря и прояснения смысла его существования. Савва составлял его с опорой на византийские агиографические традиции, часто используя элементы риторики, цитаты из Священного Писания и прибегая к параллелям деяний св. Симеона с действиями прославленных библейских персонажей. Рассказывая о мирской жизни своего героя, Савва впервые создает в сербской литературе образ идеального государственного правителя и истинного христианина. Стефан Неманя сумел укрепить сербскую державу, возвратить все утраченные ранее сербские владения, обеспечить стране мир и благополучие на протяжении всего своего 37-летнего правления. Он был набожен, христолюбив, щедро одаривал Церковь, чтил иереев, основал четыре монастыря в Топлице, Расе и Студенице, являлся надеждой для ее утративших, выступал заступником вдов и сирых, кормильцем убогих и нищих. При этом он про- 
являл равнодушие к земному богатству и власти и величайшее смирение: добровольно расстался с престолом, передал свои владения сыновьям, принял постриг и схиму и отдал Богу душу на простой рогожке, положив под голову камень, который ему принесли вместо подушки по его настоянию. Наряду с традиционной житийной топикой в этом памятнике сербской литературы присутствует многочисленные факты из древней истории сербов, отсутствующие в других письменных источниках.

Церковная же служба, сотворенная Саввой на Афоне для совершения ее 13/26 февраля в день памяти св. Симеона в храмах,

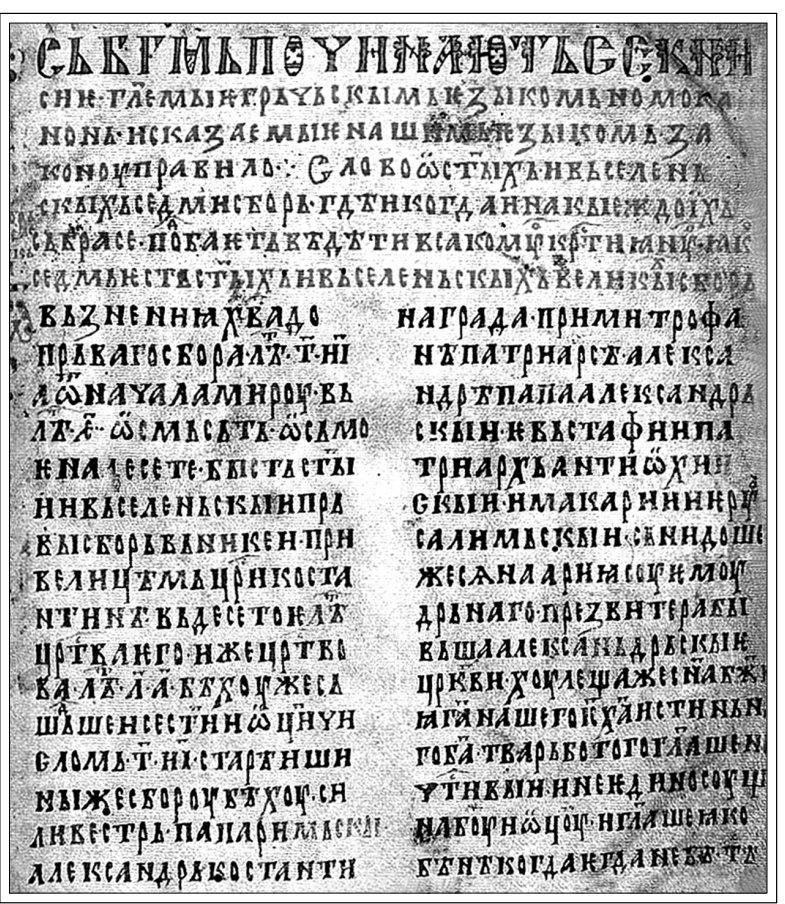

Иловицкий список Кормчей св. Саввы Сербского.

1262 г. является сугубо традиционной и подчиняется законам этого очень консервативного жанра. Они предусматривают использование веками утвержденных поэтических и певческих образцов, которые создавали знаменитые византийские гимнографы прошлого. В качестве образца для себя Савва избрал службу сирийскому подвижнику IV-V вв. Симеону Столпнику, позаимствовав из нее отдельные составляющие.

Согласно легенде, из опустевшей могилы св. Симеона на Афоне произросла чудодейственная лоза, плоды которой избавляют от бесплодия. Создав житие и службу своему отцу, Савва, образно говоря, насадил «лозу Неманичей» в слове и звуке, которая затем приобрела «триипостасьную» суть благодаря художникам, которые позднее стали изображать лозу на своих иконах и фресках. На протяжении нескольких столетий они вплетали в нее изображения представителей династии Неманичей, становившихся правителями Сербии и главами Сербской Церкви и провозглашавшихся после смерти святыми. Росла лоза, разумеется, и в слове, и в звуке: Неманичи делались героями житий, служб и различного рода церковных песнопений. С течением времени лоза все более разрасталась, давая побеги из династий и родов сербских правителей Лазаревичей, Бранковичей и Якшичей. 
Сам преподобный Савва сразу же после его кончины был провозглашен святым и «вплетен» в лозу Неманичей: местные книжники начали слагать в его честь жития, похвалы, службы, каноны, тропари и стихиры. B XIV-XV столетиях о нем писали такие знаменитые сербские книжники, как иеромонах Доментиан, Феодосий Хиландарец, архиепископ Даниил II, патриарх Даниил III и менее проявившие себя анонимные авторы. Традиция не прервалась даже после 1594 г., когда паша Синан в наказание сербам за их очередное восстание против турок приказал сжечь на холме Врачар близ Белграда сербскую национальную святыню - мощи св. Саввы, доставленные для публичного их сожжения из Милешева. Но этот акт не уменьшил почитания сербами своего небесного защитника и покровителя. В народе не переставали возникать устные легенды о св. Савве, связанные с его прижизненными чудесами, духовной прозорливостью и передвижениями по сербской земле. Ощущение незримого присутствия св. Саввы стало частью сербского национального самосознания и основой феномена, называемого «Святосавье». Именем подвижника в Сербии названы корабли, заводы, фирмы, учебные заведения и издательства. Возведенный в наше время на холме Врачар собор св. Саввы является самым большим православным храмом на Балканах.

Св. Савва почитался не только в Сербии - в XIV-XV вв. его культ существовал в Болгарии и через Афон проник в Московское государство. На русской почве первые сведения о подвижнике появились в результате распространения Стишного пролога с кратким житием св. Саввы. В XV в. на Руси появилась служба подвижника, которую составил книжник Феодосий. С перечнем афонских святынь и с именем св. Саввы русские монаха могли познакомиться при чтении рукописного сборника второй половины XV столетия известного книгописца Ефросина, подвизавшегося в Кирилло-Белозерском монастыре. В некоторых русских списках Кормчей было помещено небольшое житие св. Саввы, созданное, вероятно, в 1460-х гг. на русской почве. Новой вехой в распространении культа подвижника можно считать 1517 г., когда афонский старец Исайя доставил на Русь сборник с житием св. Саввы и общей похвалой ему и св. Симеону - произведениями, написанными все тем же Феодосием. Особенно возросло почитание Саввы Сербского в русской земле после того, как Хиландарский игумен Паисий привёз в 1550 г. в дар самодержцу Ивану Грозному икону с изображением свв. Симеона и Саввы и Савин крест, который подвижник носил до своего пострижения на Афоне. Имел значение и тот факт, что в жилах русского самодержца текла сербская кровь (его бабкой являлась сербка Анна из рода Якшичей). B XV-XVII столетиях произведения Феодосия бытовали в Московском государстве во множестве списков. Данные из его жития Саввы использовали составители всемирно-исторического свода Русского Хронографа 1516-1522 гг. В 30-е годы того же века они вошли в Никоновскую летопись, а через нее и в знаменитый Лицевой Летописный свод 1560-х-1570-х годов. 
О большом почитании св. Саввы Сербского на русской земле свидетельствует создание местными мастерами многочисленных стенописей, икон и миниатюр с изображениями подвижника. Древнейшее из них, датированное 1564 г., находится на одном из столпов Архангельского собора Московского Кремля - усыпальницы русских великих князей и царей до Петра I. Чуть позднее московские художники создали для Лицевого Летописного свода несколько миниатюр, связанных с иконографией св. Саввы Сербского. Помимо Москвы, иконы сербского подвижника широко распространялись на севере и западе страны: в Ярославле, Романове, Вологде, псковских землях и других пределах нарождавшейся Российской империи. Почитание Саввы Сербского не ослабло в России и поныне - каждый год в православных монастырях и храмах страны 12/25 января славится имя этого святителя и совершается посвященная ему церковная служба.

\section{ЛИТЕРАТУРА}

Алексеев С.В. Жития святых Симеона и Саввы. Жития королей и архиепископов

Сербских. Памятники сербской средневековой агиографии XIII-XVII вв. Санкт-Петербург, 2016. Т. I. 720 с.

Ђоровић Ђ. Списи Святому Саве. Београд, Сремски Карловци. Српска Краљевска Академија, 1928.

\section{СПИСОК ИЛЛЮСТРАЦИЙ}

1. Карея - управленческий центр афонского монастырского содружества.

2. Афонский Хиландарский монастырь.

3. Хиландарский типик.

4. Монастырь Успения Богородицы в Студенице - задужбина Стефана-Симеона Немани.

5. Монастырь Св. Спаса Вседержителя в Жиче - центр созданного в XIII в. автокефального Сербского архиепископства.

6. Иловицкая Кормчая. 1262 г.

7. Лоза Неманичей. Собор Св. Спаса Вседержителя в Жиче. XIV в.

8. Св. Савва. Стенопись в монастыре Вознесения Христова в Милешево, где покоились мощи преподобного. XIV в.

9. Свв. Савва и Симеон Сербские. Роспись Архангельского собора Московского Кремля. 1564 г.

10. Храм св. Саввы в Белграде. XX-XXI в. 